\title{
Effect of sintering temperature on the alumina extraction from kaolin
}

\author{
A.B. ElDeeb \\ Ph.D. student, Metallurgy Department, Saint-Petersburg Mining University, Saint-Petersburg, Russia \\ Assistant lecturer, Mining and petroleum department, Faculty of Engineering, Al-Azhar University in Cairo, \\ Egypt \\ V.M. Sizyakov \\ Professor, Metallurgy Department, Saint-Petersburg Mining University, Saint-Petersburg, Russia \\ V.N. Brichkin \\ Professor, Head of Metallurgy Department, Saint-Petersburg Mining University, Saint-Petersburg, Russia \\ R.V. Kurtenkov \\ Assistant, Metallurgy Department, Saint-Petersburg Mining University, Saint-Petersburg, Russia
}

\begin{abstract}
Solid state, phase transformation mechanism during the thermal decomposition of kaolin-limestone mixture sintered at different temperatures were investigated. The effect of sintering temperature on the phase transformation and alumina extraction efficiency were studied. Sintering of the mixture was carried out in the temperature range $800-1400^{\circ} \mathrm{C}$, followed by leaching with sodium carbonate solution. Leaching was carried out under the following conditions; sodium carbonate solution concentration of $120 \mathrm{~g} / 1$ at a temperature of $70^{\circ}$ $\mathrm{C}$ for 30 minutes and at a stirring speed of $600 \mathrm{rpm}$. During sintering, kaolinite decomposes and transferred into the metakaolinite phase, which in turn reacts with the decomposed calcium carbonate and forms at a certain temperature calcium aluminate phases $\left(12 \mathrm{CaO} .7 \mathrm{Al}_{2} \mathrm{O}_{3}\right)$ that are readily soluble in sodium carbonate solution. The obtained results indicate that is the sintering temperature has a significant effect on the phase transformation and the efficiency of alumina extraction. Low sintering temperatures are not enough for the main phase transformations and the formation of readily soluble forms of calcium aluminate. It is clear that, increasing the temperature to $1360^{\circ} \mathrm{C}$ increases the degree of extraction of alumina in the solution to $80.49 \%$. At the same time, the increase in the sintering temperature has a positive effect on the degree of completion of the self-disintegration process.
\end{abstract}

Keywords: alumina extraction, kaolin, solid state transformation, sintering temperature, kaolin-limestone mixture, self-disintegration process, microstructure composition

\section{INTRODUCTION}

Alumina is an important industrial material, which can be used as an abrasive material and as adsorbent (Salahudeen et al., 2015). Alumina has been widely used in advanced technological applications including its use for the processing of high-quality insulators (Ueki et al., 2010), semiconductors (Lee et al., 2013), microelectronics (Imanaka, 2015), high-strength materials (Lee et al., 2009), ceramics, refractories (Andrews et al., 2014), biofuel and cell-fuel (Phung et al., 2014), fireproof plastics, high-grade polishes (Lei et al., 2012), catalysts (Osman et al., 2017), electrochemical anodic oxidation (Wan et al., 2018), metal-matrix composites (Garg et al., 2019), the production of aluminum metal (Kvande, 2014) and a plurality of other uses. 
The aluminum industry is one of the fastest growing global sectors in the world, especially among developing countries. Increased worldwide demand for aluminum oxide, currently at more than 160 million tons per year, is expected to lead to a gradual global decline of highgrade bauxite, the ore from which alumina is mainly produced using the Bayer process. Many aluminum-producing countries have thus become increasingly interested in the investigation of producing alumina from non bauxitic sources (ElDeeb et al., 2019, Cohen \& Mercier, 2016, Protosenya \& Trushko, 2007).

Low-grade bauxites and non-bauxite resources such as nepheline, coal fly ash, clays and red mud are widely distributed in the world (Brichkin, et al., 2019, ElDeeb \& Brichkin, 2018, Dubovikov \& Brichkin, 2016, Sizyakov \& Brichkin, 2018, Sizyakov, 2005).

Clay is one of the numerous aluminous raw materials that are distributed on a large scale in the world. Among the clay group kaolin and kaolinite-based solid wastes such as coal fly ash and oil shale have attracted considerable attention for alumina extraction due to the high content of alumina in these ores (Brichkin et al., 2019, ElDeeb \& Brichkin, 2018, Olaremu, 2015, Seyed, et al., 2011, Sizyakov et al., 2019, Guo et al., 2014, Lima et al., 2014, Suss et al., 2014; Xiao et al., 2015).

Among the different clays, kaolin seems to be a more attractive candidate for alumina production and an aluminum resource alternative to bauxite, due to its high aluminium content $(35-38 \%)$ and the reactivity of kaolin increases after the dehydration transformation of the kaolin to amorphous metakaolinite, which is more reactive and from which alumina can be easily extracted by acidic or alkaline leaching agents (ElDeeb \& Brichkin, 2018, Seyed et al., 2011).

The lime sinter process for processing clay consists of the following sequential steps: 1) mixing the ground clay and calcium carbonate in proportions to give after sintering at a suitable temperature a mixture corresponding to the composition of $\left(2 \mathrm{CaO} \cdot \mathrm{SiO}_{2}\right)$, $\left(12 \mathrm{CaO} \cdot 7 \mathrm{Al}_{2} \mathrm{O}_{3}\right)$ and $\left(\mathrm{CaO} \cdot \mathrm{Al}_{2} \mathrm{O}_{3}\right)(2)$ leaching of the calcium aluminate compounds by dilute sodium carbonate solution to extract alumina in the form of sodium aluminate, (3) treating the sodium aluminate solution with carbon dioxide to precipitate alumina trihydrate (gibbsite) and (4) calcining the gibbsite at $1350^{\circ} \mathrm{C}$ to produce alumina $\left(\alpha \mathrm{Al}_{2} \mathrm{O}_{3}\right)$ phase (Al Ajeel et al., 2014, Sizyakov, 2016).

Thermal treatments at a controlled temperature range were generally applied to increase the activity of kaolin before the acidic and alkaline extraction procedure due to the low chemical reactivity of kaolinite (Sizyiakov et al., 2013). The process is generally thought to increase clay reactivity by affecting dehydration transformation of the kaolin to amorphous metakaolinite $\left(\mathrm{Al}_{2} \mathrm{Si}_{2} \mathrm{O}_{7}\right)$, which is known to be more reactive and from which alumina can be easily extracted by acidic or alkaline leaching agents (Cohen \& Mercier, 2016, Sizyiakov, 2006).

In this work, the effect of sintering temperature, solid state and phase transformation mechanism on the alumina extraction efficiency from kaolin ore processed using lime-sinter process were investigated. The efficiency of the self-disintegration process as a result of the sintering process was also studied. The micro structure changes in the produced sinters and sludges due to the sintering process were investigated.

\section{MATERIALS AND METHODS}

The current study was carried out using kaolin ore which was obtained from Irkutsk mining site, while limestone ore sample was obtained from Pikalevo region, Russia. Chemically pure grade up to $99.8 \%$ sodium carbonate was used for the leaching process.

The chemical composition of the kaolin and limestone ores was determined using XRF1800 sequential X-ray fluorescence spectrometer $(40 \mathrm{kV}, 90 \mathrm{~mA}, \mathrm{Re}$ anode) (USA) in order to estimate the chemical composition of the raw materials and the chemical changes that took place after the sintering and the leaching processes. Structural phase analysis of the kaolin ore was carried out using a bruker D8 focus X-ray diffractometer having siemens diffractometer 7000 with $\mathrm{Cu}-\mathrm{K} \alpha$ radiation $(40 \mathrm{kV}, 30 \mathrm{~mA}, \lambda=1.5406 \AA$ ) (USA). 
Differential scanning calorimetry (DSC) and thermal gravimetric analysis (TGA) for kaolin-limestone mixture were investigated using simultaneous DSC-TGA instrument (SDT Q600) (USA) in the temperature range from ambient to $1300^{\circ} \mathrm{C}$ and heating rate of $20^{\circ} \mathrm{C} / \mathrm{min}$ in the air conditions in order to clarify the thermal decomposition behavior of kaolinlimestone mixture. The particle size analysis for the produced sinter and sludge was carried out by laser microanalysis using the domestic microsizer $201 \mathrm{C}$ analyzer and the range of analysis was 0.2 to $600 \mu \mathrm{m}$.

The microstructure changes of the sintered kaolin-limestone mixture as a result of the sintering process at different temperatures and the sludge produced as a result of the subsequently leaching were characterized using a tescan TS 5130MM scanning electron microscope equipped with an X-ray energy dispersive detector (manufactured by Oxford Instruments, active crystal area $-50 \mathrm{MM}^{2}$ ) with the INCA energy microanalysis system and YAG crystal as a reflected electron detector.

The kaolin-limestone mixture was prepared according to the stoichiometric calculations on the basis of the molar ratios of oxides $\left[\mathrm{CaO} / \mathrm{SiO}_{2}=2, \mathrm{CaO} / \mathrm{Al}_{2} \mathrm{O}_{3}=1.8\right.$ and $\left.\mathrm{CaO} / \mathrm{Fe}_{2} \mathrm{O}_{3}=1\right]$ and the prepared charge according to this stoichiometry composed of $265.8 \mathrm{~g}$ limestone and $100 \mathrm{~g}$ kaolin. These ratios provide the required phases suitable for the leaching process and the higher recovery of alumina (Al-Ajeel et al., 2014, ElDeeb et al., 2019).

The kaolin-limestone mixture was effectively mixed in a drum mixer for $4 \mathrm{hr}$ then formed on the form of cylindrical briquettes. Briquetting was carried out on the hydraulic press "Laptuls" using the press mould of $30 \mathrm{~mm}$ diameter and $30 \mathrm{~mm}$ height at $5 \mathrm{MPa}$ briquetting pressure (ElDeeb et al., 2019). The produced briquettes was sintered in a laboratory high-temperature chamber furnace in closed air conditions in the temperature range from $800^{\circ} \mathrm{C}$ to $1400^{\circ} \mathrm{C}$ and for $1 \mathrm{hr}$. In the sintering process, the briquettes were inserted in the furnace then the furnace started to heat at the predetermined temperature with a rate of $10^{\circ} \mathrm{C} /$ minute. After reaching the desired temperature, the duration of the isothermal holding at the given temperature was $1 \mathrm{hr}$. After finishing the sintering time, the furnace was allowed to cool down to the room temperature in order to allow the sintered material to be annealed and achieve the self-disintegration process. The obtained sintered material was characterized chemically using XRF analysis in order to determine the oxides content in the produced sinter and mineralogically using XRD analysis in order to determine the new phases as a result of the sintering process at different temperatures. The microstructure changes of the sintered kaolin-limestone charge as a result of the sintering process and the sludge produced as a result of the subsequently leaching were characterized using scanning electron microscope (SEM-EDX).

The sinters obtained from the sintering process were leached using $\mathrm{Na}_{2} \mathrm{CO}_{3}$ solution. The leaching process was carried out in the HEL Auto-Mate II reactor system equipped with mechanical stirring. All leaching experiments for the produced sinter at differant temperatures were carried out under the following conditions: $70^{\circ} \mathrm{C}$ leaching temperature, $\mathrm{Na}_{2} \mathrm{CO}_{3}$ solution with a concentration $120 \mathrm{~g} / \mathrm{l}$ solution, $1 / 5$ solid to liquid ratio, $30 \mathrm{~min}$. leaching time and $600 \mathrm{rpm}$ stirring speed according to the best condition obtained before (ElDeeb et al., 2019). The produced pulp from the leaching process was filtered out using a vacuum and the obtained sludge was washed with hot distilled water then dried in the draying furnace. The obtained sludge's were analyzed chemically by XRF analysis in order to determine the oxides content in the sludge. The alumina extraction degree was calculated using the following formula: $\mathrm{Al}_{\text {extracted }}=\left(\mathrm{A} 1_{\text {sinter }}-\mathrm{Al}_{\text {sludge }}\right) / \mathrm{A} 1_{\text {sinter. }}$

\section{RESULTS AND DISCUSSION}

\subsection{The physical and chemical characterization of the used raw materials}

The mineralogical analysis of the kaolin ore sample using XRD analysis shown in Figure 1, revealed that the kaolin ore composed mainly from kaolinite mineral $\left(\mathrm{Al}_{2} \mathrm{O}_{3} \cdot 2 \mathrm{SiO}_{2} \cdot 2 \mathrm{H}_{2} \mathrm{O}\right)$ barring aluminium oxide and silica contributions, which were also detected as quartz mineral. The chemical analysis of the kaolin ores using XRF analysis shown in Table 1 indicates that is 


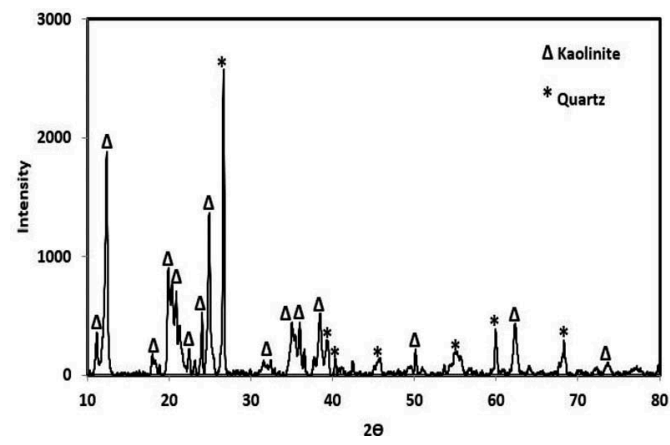

Figure 1. XRD analysis of the kaolin ore.

Table 1. The chemical analysis of the kaolin and limestone ores.

\begin{tabular}{lcclcccccc}
\hline Materials & $\mathrm{SiO}_{2}$ & $\mathrm{Al}_{2} \mathrm{O}_{3}$ & $\mathrm{Fe}_{2} \mathrm{O}_{3}$ & $\mathrm{TiO}_{2}$ & $\mathrm{CaO}$ & $\mathrm{Na}_{2} \mathrm{O}$ & $\mathrm{K}_{2} \mathrm{O}$ & others & L.O.I \\
\hline Kaolin ore & 52.2 & 31.9 & 1.4 & 0.58 & 0.59 & 0.15 & 0.15 & 0.03 & 13 \\
Limestone & 2.01 & 0.41 & 0.56 & 0.58 & 53.3 & - & - & - & 43.14 \\
\hline
\end{tabular}

the kaolin ore contains $31.9 \% \mathrm{Al}_{2} \mathrm{O}_{3}$ and $52.2 \% \mathrm{SiO}_{2}$ which represent the main components of the kaolin ore in addition to other oxides. The loss on ignition of $13 \%$ in the chemical analysis is as a result of organic matter, some non-metals and the chemical and physical water lost. This alumina content in kaolin ore is considered as economic percentage for the extraction of alumina in comparison with bauxite ore (Brichkin et al., 2019).

The TGA and DSC analysis for the kaolin-limestone mixture is shown in Figure 2. The TGA curve of the kaolin-limestone mixture sample show three well-defined weight loss regions, the first is below $200^{\circ} \mathrm{C}$ and the endothermic peak in the DSC curve at $111.20^{\circ} \mathrm{C}$ is due to the loss of physisorbed water. The seconded weight loss region in the TGA curve is above $450^{\circ} \mathrm{C}$ and the endothermic peak in the DSC curve at $507.51^{\circ} \mathrm{C}$ is due to the dehydroxylation of coordinated and structural water with a weight loss of $3.27 \%$. The third weight loss regions in the TGA curve is in the range $\left(650-850^{\circ} \mathrm{C}\right)$ and the endothermic peak in the DSC curve at $844.43^{\circ} \mathrm{C}$ can be attributed to the complete dissociation of the limestone and the further release of $\mathrm{CO}_{2}$ from $\mathrm{CaCO}_{3}$ with a weight loss of $29.69 \%$. Compared with the

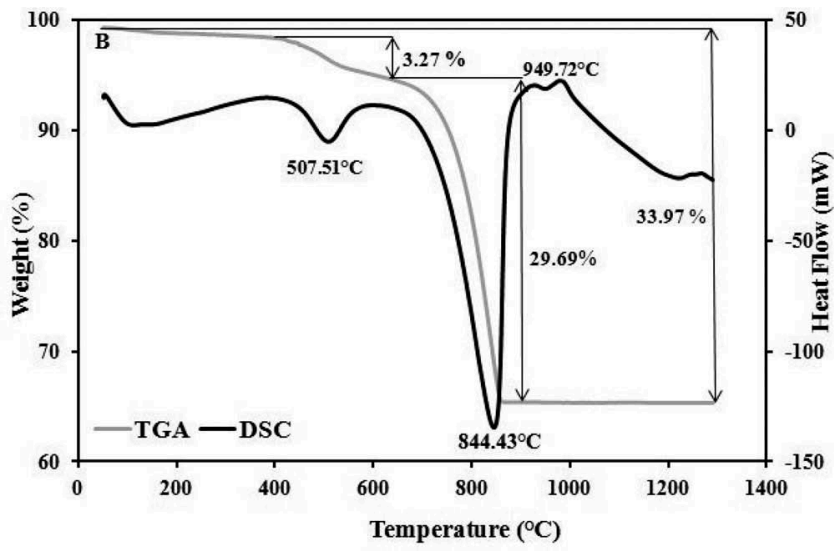

Figure 2. DSC and TGA analysis for the kaolin-limestone mixture. 
decomposition temperature of pure $\mathrm{CaCO}_{3}\left(650-900^{\circ} \mathrm{C}\right)$, the existence of kaolinite obviously decreased the decomposition temperature of $\mathrm{CaCO}_{3}$ in the mixture, which suggested that the solid-state reaction between kaolinite and $\mathrm{CaCO}_{3}$ occurred during the heating process (Tian et al., 2016, Yan et al., 2017, Zhang et al., 2015). The sharp exothermic peak at $949.52^{\circ} \mathrm{C}$ could be assigned to the phase transformation from metakaolinite to Al-Si spinel or mixture of $\gamma$-alumina, amorphous silica and mullite and the total weight loss is $33.97 \%$ at $1300^{\circ} \mathrm{C}$ (Zhang et al., 2015, ElDeeb et al., 2019). Also it is clear that the existence of calcite $\left(\mathrm{CaCO}_{3}\right)$ obviously decreased the phase transformation temperature from metakaolinite to Al-Si spinel or the mixture of $\gamma$-alumina, amorphous silica and mullite compared to this temperature for the TGA and DSC analysis of the kaolin ore.

\subsection{The effect of sintering temperature on the percent recovery of alumina}

The most important factor affecting on the physico-chemical transformation of the kaolinlimestone mixture and hence the extraction of alumina from kaolin ore is the sintering temperature. The effect of the sintering temperatures on the percent recovery of alumina from kaolin ore was investigated in the range from 800 to $1400^{\circ} \mathrm{C}$. The obtained sinters at different sintering temperatures and the sludges as a result of the subsequently leaching of these sinters were characterized chemically using XRF analysis in order to determine the oxides content in both the sinters and sludges. The effect of the sintering temperatures on the oxides content in the sinters is shown in Figure 3A. The oxides content in the sludges produced from the subsequently leaching of the sinter is shown in Figure 3B. The chemical composition indicates that both the sinter and sludge composed mainly from the following oxides $\mathrm{CaO}, \mathrm{SiO}_{2}, \mathrm{Al}_{2} \mathrm{O}_{3}$ in addition to other oxides. The difference between the alumina content in the sinter and its content in the sludge represent the percent recovery of alumina in the solution and the alumina extraction degree was calculated using the following formula: $\mathrm{Al}$ extracted $=\left(\mathrm{Al}_{\text {sinter }}-\mathrm{Al}_{\text {sludge }}\right) / \mathrm{Al}_{\text {sinter }}$ as shown in Figure 4.

It is clear that is the percent recovery of alumina increases with increasing the sintering temperature from 800 to $1360^{\circ} \mathrm{C}$ and then with more increasing of the sintering temperature up to
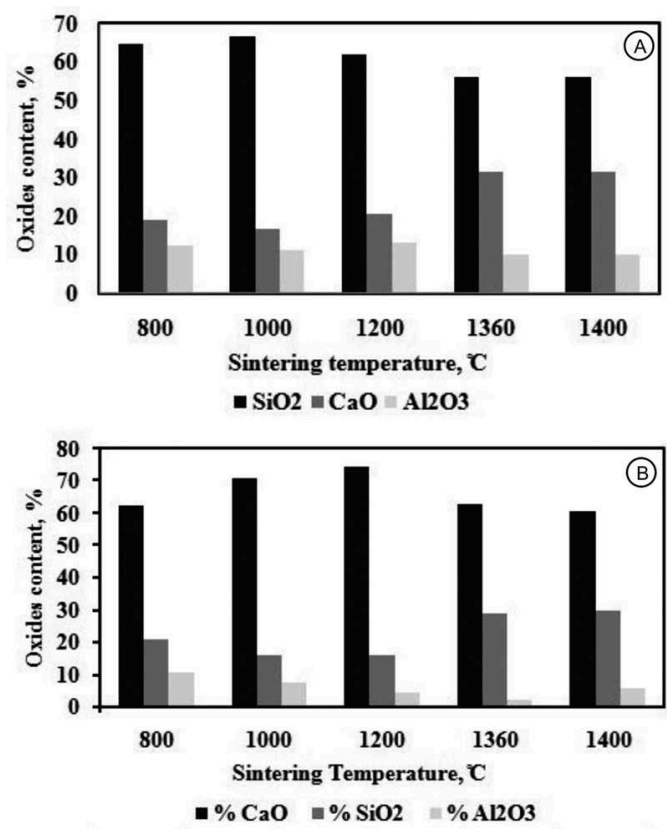

Figure 3. The effect of the sintering temperature on the oxides content obtained in a) the sintered kaolin-limestone mixture and $\mathrm{b}$ ) the sludge produced from the leaching process. 


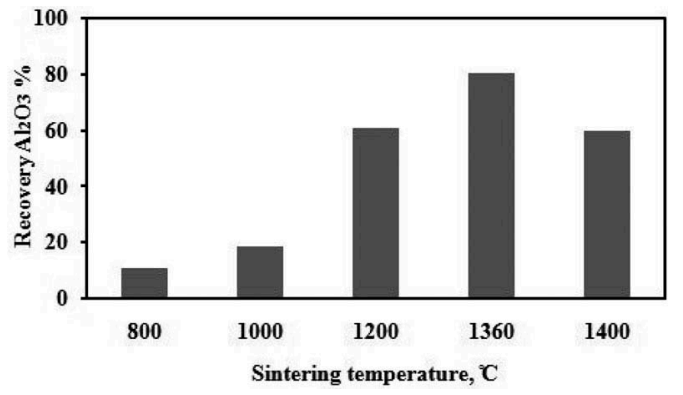

Figure 4. The effect of sintering temperature on the percent recovery of alumina.

$1400^{\circ} \mathrm{C}$ the percent recovery of alumina decreases. The percentage recovery of alumina increases from $10.51 \%$ at $800^{\circ} \mathrm{C}$ to 80.49 at $1360^{\circ} \mathrm{C}$ then decrease to $59.70 \%$ at $1400^{\circ} \mathrm{C}$. This can be attributed to that is the sintering temperature of $1360^{\circ} \mathrm{C}$ is the most suitable temperature for the formation of $\mathrm{C}_{2} \mathrm{~S}$ and $\mathrm{C}_{12} \mathrm{~A}_{7}$ compounds in the sinter at which alumina can be extracted easily from the $\mathrm{C}_{12} \mathrm{~A}_{7}$ using sodium carbonate solution. The low temperature isn't sufficient for the complete decomposition of the calcium carbonate and the formation of the $\mathrm{C}_{2} \mathrm{~S}$ and $\mathrm{C}_{12} \mathrm{~A}_{7}$ compounds hence the lost of alumina in the form of $\mathrm{Al}_{2} \mathrm{SiO}_{5}$ and $\mathrm{Ca}_{2} \mathrm{Al}_{2} \mathrm{SiO}_{7}$. On the other hand, decreasing the percent recovery of alumina with more increasing of the sintering temperature up to $1400^{\circ} \mathrm{C}$ can be attributed to the high temperature which leads to the formation of mullite $\left(\mathrm{Al}_{2} \mathrm{O}_{3} \cdot \mathrm{SiO}_{2}\right)$ phase from which alumina is difficulty extracted (Qiao, et al., 2008).

\subsection{The effect of sintering temperature on the solid state and phase transformation mechanism}

The effect of the sintering temperature on the phase transformation mechanism of kaolin- limestone mixture was carried out by studying the microstructure changes in both the sinters and sludges produced at differant temperatures. The main structural components of both the sinter produced at $800^{\circ} \mathrm{C}$ and the sludge obtained from its subsequently leaching are shown in Figure 5 . The results indicate that the main structural components in both the sinter and sludge include: relics of the original charge minerals including kaolinite and calcite. Other components including particles of silicon dioxide, magnetite, rutile, ilmenite, iron-chromium spinels and calcite which are strictly subordinate. In addition, traces of the sludge contain traces of finely dispersed highly porous carbonate mass surrounding the relics of kaolin particles.
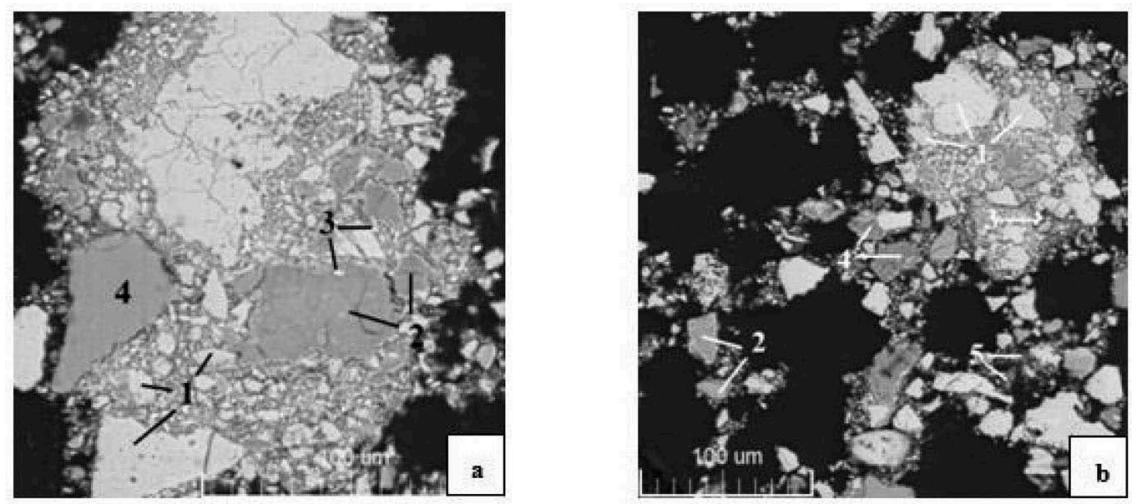

Figure 5. The main structural components of (a) the sinter and (b) the sludge samples produced at $800^{\circ} \mathrm{C}$ where, 1- calcium carbonate, 2- relics of kaolin, 3- particles of magnetite/rutile/other heavy impurities components of the charge, 4- silicon dioxide and 5- fine carbonate mass. 
It can be concluded, that is the sintering temperature of $800^{\circ} \mathrm{C}$ is not sufficient to the decomposition and dissociation of the calcium carbonate. There for, there is no solid state reaction between metakaolinite produced from the dehydroxylation of kaolin ore and the calcium carbonate. It was also noted that the formation of calcium aluminates in the sintered material is not marked and this means that this temperature is not sufficient to the formation of this phase from which alumina can be extracted easily. This explains the lower recovery of alumina from the sinter produced at this temperature as shown in Figure 4 and this means that is the extraction of alumina is carried out from the metakaolinite particles. It was also detected that is the aluminum in the samples of both sinter and sludge produced at $800^{\circ} \mathrm{C}$ is concentrated in kaolin relics.

The main structural components of both the sinter and sludge produced at $1000^{\circ} \mathrm{C}$ are illustrated in Figure 6. It Indicate that both of them have mainly the same composition of relics of calcium carbonates, relics of kaolin, secondary aluminosilicate rims, and silicon dioxide except the sludge contains fine carbonate mass. It was found that the degree of change of these structures are much higher than that occurred at $800^{\circ} \mathrm{C}$. It can be seen that; nearly most of calcium carbonates is characterized by a high degree of decomposition up to complete destruction. On the other hand for kaolin, it is shown that secondary aluminosilicate rims of a wide range of composition are present on the surface.

The main structural components of the sinter produced at $1360^{\circ} \mathrm{C}$ are illustrated in Figure $7 \mathrm{a}$. The most common components in the sinter are aluminosilicate components of a wide range of composition, calcium silicate and calcium aluminate. These components are presented both in the form of free particles and in association with each other and the other components. The main structural components of the sludge produced at $1360^{\circ} \mathrm{C}$ are illustrated in Figure $7 \mathrm{~b}$. It is clear that the most common components in the sludge are aluminosilicate components of a wide range of composition. It was also noted that the main structural components of the sludge is nearly the same for the sinter in addition to the presence of $\mathrm{CaCO}_{3}$ as a result of the leaching process. Also in the structural components of the sinter and sludge it was noted that, in addition to aluminosilicates, calcium silicates and calcium aluminates of variable composition with noticeable admixtures of other elements are subordinate to the samples. It was noted that the content of aluminates in the sample of sludge is significantly lower than its content in the sinter sample that explains the higher recovery of alumina at this sintering temperature (ElDeeb et al., 2019).

\subsection{The effect of sintering temperature on the efficiency of the self-disintegration process}

The sintering temperature has also a significant effect on the efficiency of the selfdisintegration process and the completeness of the phase transformations, hence the
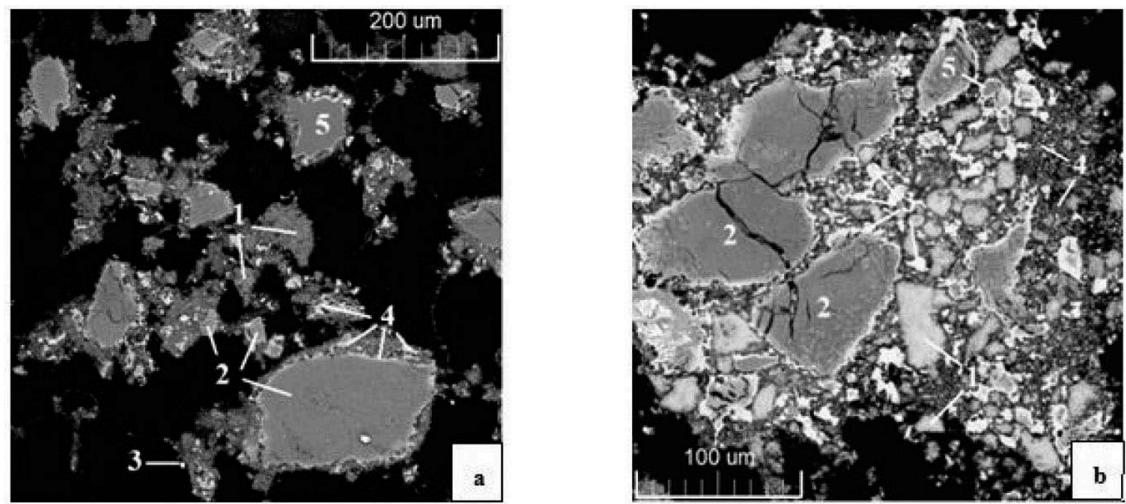

Figure 6. The main structural components of the (a) sinter produced at $1000^{\circ} \mathrm{C}$ where, 1- relics of calcium carbonate, 2- relics of kaolin, 3- particles of magnetite/rutile/other heavy impurities of the charge, 4- secondary aluminosilicate rims and 5- silicon dioxide. (b) the sludge sample where, 1- relics of carbonates, 2- relics of kaolin, 3- secondary aluminosilicate rims, 4- fine carbonate mass and 5- silicon dioxide. 

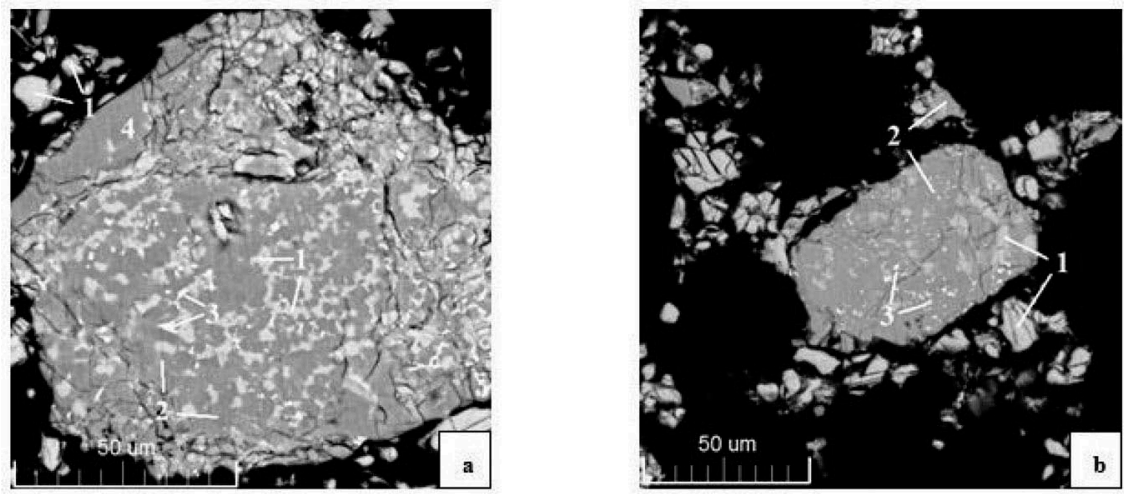

Figure 7. The main structural components of the sinter sample produced at $1360^{\circ} \mathrm{C}$ where, 1 - calcium silicates, 2- aluminosilicates, 3- particles of magnetite/rutile/other heavy impurity components of the charge, 4- calcium aluminates and 5- carbonate components. (b) the sludge sample where, 1- calcium silicates, 2- aluminosilicates of a wide range of composition, 3- particles of magnetite/rutile/other heavy impurity components of the charge, 4- carbonate components and 5-calcium aluminates.

extraction of alumina. The lower sintering temperatures $\left(800-1200^{\circ} \mathrm{C}\right)$ are not sufficient for the formation of calcium silicates $\left(\mathrm{C}_{2} \mathrm{~S}\right) . \mathrm{C}_{2} \mathrm{~S}$ undergoes a crystallographic transformation on cooling with an increase in the molar volume due to the transformation of $2 \mathrm{CaO} \cdot \mathrm{SiO}_{2}$ from $\beta$ to $\gamma$ form as shown in following equation. In contrast, high sintering temperatures $\left(1300-1400^{\circ} \mathrm{C}\right)$ are sufficient for the formation of $\mathrm{C}_{2} \mathrm{~S}$ in sufficient amounts that leads to the transformation of the sintered briquettes into fine powder, which increases the solubility of the alumina containg compounds without any need for further grinding (Stange et al., 2017).

$$
\beta-\mathrm{Ca}_{2} \mathrm{SiO}_{4} \stackrel{675^{\circ} \mathrm{C}}{\longrightarrow} \gamma-\mathrm{Ca}_{2} \mathrm{SiO}_{4}
$$

The results of the particle size analysis of the produced sinter and sludge using the domestic microsizer $201 \mathrm{C}$ analyzer is shown in Figure 8. It is clear that there is an enlargement in the particle size of the sludge obtained after the leaching process compared to the size of the sinter. The agglomeration and the increase in particle size of the produced sludge can be attributed to the formation of $\mathrm{CaCO}_{3}$ at the surface of the produced sludge (Zhang, et al., 2015).
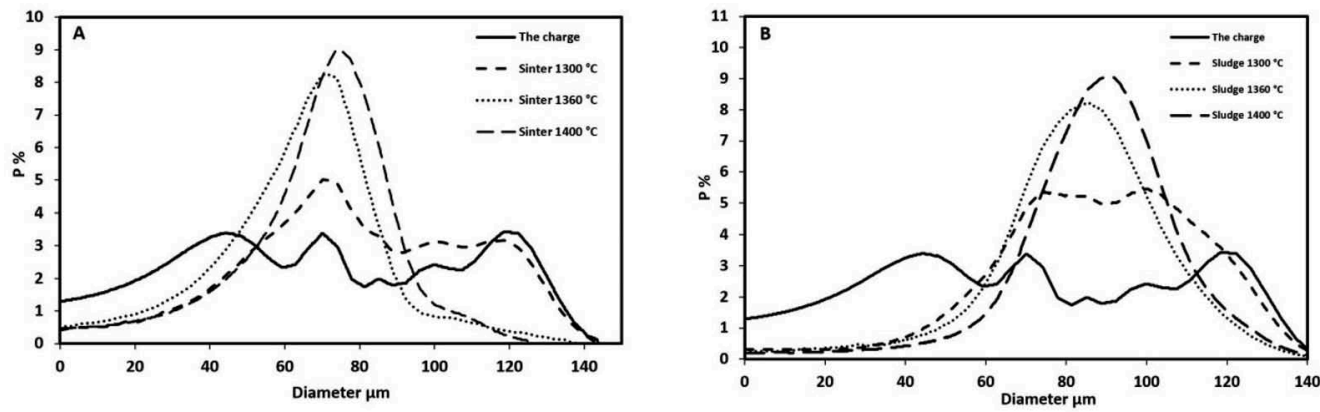

Figure 8. The effect of the sintering temperature on the particle size of the (A) sinter and (B) sludge obtained at different sintering temperature. 


\section{CONCLUSION}

The obtained results indicate that is the sintering temperature has a significant effect on the solid state, phase transformation mechanism and hence the efficiency of alumina extraction from kaolin ore processed using lime-sinter process. The lower sintering temperatures are not enough for the melting of the original compounds of the charge and the solid state reaction between the metakaolinite and calcium carbonate doesn't occur. The extraction of alumina is carried out only from metakaolinite that explains the lower recovery of alumina at this temperature of about $10.51 \%$ at $800^{\circ} \mathrm{C}$. The higher sintering temperatures are enough for the complete dehydroxylation of kaolinite and decomposition of calcium carbonate and at the same time the melting of the original constituents with the formation of calcium aluminates and calcium silicates in different forms. These temperatures enhancing the extraction of alumina to be $60.74 \%$ at $1000^{\circ} \mathrm{C}$ and $80.49 \% \%$ at $1360^{\circ} \mathrm{C}$. The more increase in the sintering temperature more than $1360^{\circ} \mathrm{C}$ leads to the formation of mullite phase $\left(3 \mathrm{Al}_{2} \mathrm{O}_{3} \cdot 2 \mathrm{SiO}_{2}\right)$ with higher percentage from which it is difficult to extract alumina which explains the decreasing of alumina extraction at $1400^{\circ} \mathrm{C}$ to about $59.70 \%$. Thus, it is obvious that is the sintering temperature of $1360^{\circ} \mathrm{C}$ is the most suitable temperature for the higher extraction of alumina from kaolin. The agglomeration of secondary $\mathrm{CaCO}_{3}$ particles on the surface of the insoluble particles is the dominant mechanism of increasing the particle size of the produced sludge compared to the original particle size of the obtained sinter.

\section{ACKNOWLEDGMENT}

The work was carried out with the financial support of the Russian Science Foundation under the agreement No. 18-19-00577 of April 262018 of grant for fundamental scientific research and exploratory scientific research.

\section{REFERENCES}

Al-Ajeel, A.A. \& Abdullah, S.Z. \& Muslim, W.A. \& Abdulkhader, M.Q. \& Al-Halbosy, M.K. \& AlJumely, F.A. 2014. Extraction of Alumina from Iraqi colored kaolin by lime-sinter process. Iraqi Bull. Geol. Min. 10 (3): 109-117.

Andrews, A. \& Nsiah-Baafi, E. \& Gawu, S.K.Y. \& Olubambi, P.A. 2014. Synthesis of high alumina refractories from lithomargic clay. Ceramics International 40 (4): 6071-6075.

Brichkin, V.N. \& Kurtenkov, R.V. \& ElDeeb, A.B. \& Bormotov, I.S. 2019. State and development options for the raw material base of aluminum in non-bauxite regions. Obogashchenie Rud 4: 31-37.

Cohen, J. \& Mercier, H. 2016. Recovery of alumina from Non-Bauxite aluminum-bearing raw materials. In: Donaldson D., Raahauge B.E. (eds.) Essential Readings in Light Metals. Springer, Cham. 1057-1064.

Dubovikov, O.A. \& Brichkin, V.N. 2016. Directions and prospects of using low grade process fuel to produce alumina. Journal of Mining Institute 220: 587-594.

ElDeeb, A.B.S. \& Brichkin, V.N. 2018. Egyptian aluminum containing ores and prospects for their use in the production of Aluminum. Int. J. Sci. Eng. Res. 9 (5): 721-731.

ElDeeb, A.B. \& Brichkin, V.N. \& Kurtenkov, R.V. \& Bormotov, I.S. 2019. Extraction of alumina from kaolin by a combination of Pyro- and hydrometallurgical Processes. Applied Clay Science 172: 146-154.

Imanaka Y., 2015. Materials and processes of microelectronic packing including low temperature cofired ceramics technology (past, present and future). J. Ceram. Sci. Tech. 6 (4): 291-300.

Garg, P. \& Jamwal, A. \& Kumar, D. \& Sadasivuni, K.K. \& Hussain, C.M. \& Gupta, P. 2019. Advance research progresses in aluminium matrix composites: manufacturing \& applications. Journal of Materials Research and Technology 8 (5): 4924-4939.

Kvande, H. 2014. The Aluminum Smelting Process. Journal of Occupational and Environmental Medicine 56: S2-S4.

Lee, J.S. \& Kim, H.S. \& Park, N.-K. \& Lee, T.J. \& Kang, M. 2013. Low temperature synthesis of $\alpha-$ alumina from aluminum hydroxide hydrothermally synthesized using $\left[\mathrm{Al}\left(\mathrm{C}_{2} \mathrm{O}_{4}\right) \mathrm{x}(\mathrm{OH}) \mathrm{y}\right]$ complexes. Chemical Engineering Journal 230: 351-360.

Lee, S.O. \& Jung, K.H. \& Oh, C.J. \& Lee, Y.H. \& Tran, T. \& Kim, M.J. 2009. Precipitation of fine aluminum hydroxide from Bayer liquors. Hydrometallurgy 98 (1-2): 156-161. 
Lei, H. \& Wu, X. \& Chen, R. 2012. Preparation of porous alumina abrasives and their chemical mechanical polishing behavior. Thin Solid Films 520 (7): 2868-2872.

Lima, P.E.A. \& Angélica, R.S. \& Neves, R.F. 2014. Dissolution kinetics of metakaolin in sulfuric acid: comparison between heterogeneous and homogeneous reaction methods. Applied Clay Science 88-89 (3): $159-162$.

Olaremu, A.G. 2015. Sequential leaching for the production of alumina from a Nigerian clay. Int. J. Eng. Technol. Manag. Appl. Sci. 3 (7): 103-109.

Osman, A.I. \& Abu-Dahrieh, J.K. \& Rooney, D.W. \& Thompson, J. \& Halawy, S.A. \& Mohamed, M. A. 2017. Surface hydrophobicity and acidity effect on alumina catalyst in catalytic methanol dehydration reaction. Journal of Chemical Technology \& Biotechnology 92 (12): 2952-2962.

Phung, T.K. \& Lagazzo, A. \& Rivero Crespo, M.Á. \& Sánchez Escribano, V. \& Busca, G. 2014. A study of commercial transition aluminas and of their catalytic activity in the dehydration of ethanol. Journal of Catalysis 311: 102-113.

Protosenya A.G. \& Trushko O.V., 2007. Problems of the development of the raw material base of the aluminum industry in Russia and the organization of production in a market economy. Journal of Mining Institute 172: 132-137.

Qiao, X.C. \& Si, P. \& Yu, J.G. 2008. A Systematic Investigation into the Extraction of Aluminum from Coal Spoil through Kaolinite. Environ. Sci. Technol., 42 (22): 8541-8546.

Salahudeen, N. \& Ahmed, A.S. \& Al-Muhtaseb, A.H. \& Dauda, M. \& Waziri, S. M. \& Jibril, B. Y. 2015. Synthesis of gamma alumina from Kankara kaolin using a novel technique. Applied Clay Science 105-106: 170-177.

Seyed, A.H. \& Aligholi N. \& Dariush S. 2011. Production of $\gamma-\mathrm{Al}_{2} \mathrm{O}_{3}$ from Kaolin. Open Journal of Physical Chemistry 1: 23-27.

Sizyakov, V.M. \& Brichkin, V.N. \& ElDeeb, A. B. \& Kurtenkov, R.V. 2019. Egyptian aluminumcontaining raw materials and the prospects for its integrated processing to produce alumina and byproducts. XI International Congress \& Exhibition Non-Ferrous Metals \& Minerals, Proceedings of 37th International ICSOBA Conference, Krasnoyarsk, Russia, 16-20 September, 2019, http://nfmsib. ru/wp-content/uploads/2019/08/spisok-dokladov-Alyuminij-Sibiri_6.08.pdf.

Sizyakov, V.M. \& Brichkin, V.N. 2018. About the role of Hydrafed calcium carboaluminates in improving the technology of complex processing of nephelines. Journal of Mining Institute 231: 292-298.

Sizyakov, V.M. 2016. Chemical and technological mechanisms of a alkaline aluminum silicates sintering and a hydrochemical sinter processing. Journal of Mining Institute 217: 102-112.

Sizyiakov, V.M. \& Dubovikov, O.A. \& Nikolaeva, N.V. \& Kalashnikova, M.I. 2013. The role of mineralized additivies in the alumina phase transformation process. Journal of Mining Institute 202: 48-55.

Sizyiakov V.M. 2006. Influence of nepheline and limestone dispersion on the quality of aluminate sinter. Journal of Mining Institute 169: 35-40.

Sizyakov, V.M. 2005. Current status and problems of the Russian aluminum industry. Journal of Mining Institute 165: 163-169.

Stange, K. \& Lenting, C. \& Geisler, T. 2017. Insights into the evolution of carbonate-bearing kaolin during sintering revealed by in situ hyperspectral Raman imaging. Journal of the American Ceramic Society:1-14.

Suss, A.G. \& Damaskin, A.A. \& Senyuta, A.S. \& Panov, A.V. \& Smirnov, A.A. 2014. The influence of the mineral composition of low-grade aluminum ores on aluminium extraction by acid leaching. In: Grandfield J. (eds) Light Metals 2014, Springer, Cham,:105-109.

Tian, Y. \& Pan, X. \& Yu, H. \& Han, Y. \& Tu, G. \& Bi, S. 2016. An improved lime sinter process to produce $\mathrm{Al}_{2} \mathrm{O}_{3}$ from low-grade Al-containing resources. In: Williams E. (eds) Light Metals. Springer, Cham: $5-9$.

Ueki, Y. \& Kunugi, T. \& Morley, N.B. \& Abdou, M.A. 2010. Electrical insulation test of alumina coating fabricated by sol-gel method in molten PbLi pool. Fusion Engineering and Design 85 (10-12): $1824-1828$.

Wan, Ye \& Wang, Huan \& Zhang, Yundian \& Wang, Xiumei \& Li, Yanbo. 2018. Study on Anodic Oxidation and Sealing of Aluminum Alloy. Int. J. Electrochem. Sci. 13: 2175-2185.

Xiao, J. \& Li, F. \&, Zhong, Q. \& SS Bao, H. \& Wang, B. \& Huang, J. \& Zhang, Y. 2015. Separation of aluminum and silica from coal gangue by elevated temperature acid leaching for the preparation of alumina and $\mathrm{SiC}$. Hydrometallurgy 155: 118-124.

Yan, K. \& Guo, Y. \&, Fang, Li \& Cui, Li \& Cheng, F. \& Li, T. 2017. Decomposition and phase transformation mechanism of kaolinite calcined with sodium carbonate. Applied Clay Science 147: 90-96.

Zhang, S. \& Ou, X. \& Qiang, Y. \& Niu, J. \& Komarneni, S. 2015. Thermal decomposition behavior and de-intercalation mechanism of acetamide intercalated into kaolinite by thermoanalytical techniques. Applied Clay Science 114 (10): 309-314. 